Collection: COST Action FP0903 (2010) - Rome (Italy)

"Research, monitoring and modelling in the study of climate change and air pollution impacts on forest ecosystems"

Guest Editors: E Paoletti, J-P Tuovinen, N Clarke, G Matteucci, R Matyssek, G Wieser, R

Fischer, P Cudlin, N Potocic

\section{Towards a transnational system of supersites for forest monitoring and research in Europe - an overview on present state and future recommendations}

\author{
Fischer $\mathbf{R}^{(1)}$, Aas $\mathbf{W}^{(2)}$, De Vries $\mathbf{W}^{(3)}$, Clarke $\mathbf{N}^{(4)}$, Cudlin $\mathbf{P}^{(5)}$, Leaver $\mathbf{D}^{(6)}$, \\ Lundin $\mathrm{L}^{(7)}$, Matteucci $\mathrm{G}^{(8)}$, Matyssek $\mathrm{R}^{(9)}$, Mikkelsen TN ${ }^{\left({ }^{(0)}\right.}$, Mirtl $\mathrm{M}^{(11)}$, \\ Öztürk $Y^{(1)}$, Papale $D^{(12)}$, Potocic $N^{(13)}$, Simpson $D^{(14)}$, Tuovinen J-P(15), \\ Vesala $T^{(16)}$, Wieser $G^{(17)}$, Paoletti $E^{(18)}$
}

Science-based approaches in addressing future risks and challenges for forests require close collaboration among the communities operating different monitoring and research networks as well as experts in process and large-scale modelling. Results of the COST FP0903 conference which took place in October 2010 in Rome, reveal valuable results from different European forest monitoring and research networks. However, the need for closer integration of these activities is obvious. In this paper, representatives from major European networks recommend a new approach for forest monitoring and research in Europe, based on a reasonable number of highly instrumented "supersites" and a larger number of intensive monitoring plots linked to these. This system needs to be built on existing infrastructures but requires increased coordination, harmonisation and a joint long term platform for data exchange and modelling.

Keywords: Forest monitoring, Supersites, Research infrastructure, Europe

\section{Introduction}

Forests in Europe are expected to face significant pressures over the coming century including among others land use changes, potential overexploitation for bioenergy and biorefinery, increasing demand for conservation areas, climate change and air pollution. A better understanding of the integrated effects of different anthropogenic and natura stress factors such as air pollution, climate and global climate change on forest ecosystem functioning is of paramount importance in order to maintain, enhance and restore multiple forest ecosystem goods and services. A better integration of different forest research, monitoring and modelling activities would promote cost-efficient production and provision of information (Fischer 2008). Both scientists (Bytnerowicz et al. 2007) and policy-makers (EEA 2004) have emphasized that a better integration offers an important opportunity for capturing synergies and avoiding overlaps between different research and monitoring communities in order to use existing infrastructures more efficiently.

The knowledge on current transnational networks is an essential basis to enable better integration and cooperation and to maximise the use of existing infrastructure and data. The COST Action FP0903 (COST 2010) provides a platform for information exchange, the analysis of the present situation and the elaboration of recommendations for the creation of an integrated system of monitoring and research sites. The need for so-called supersites needs to be explored in this context. The present paper summarizes presentations and round-table discussions at the COST FP0903 conference held in Rome in October 2010 aiming to identify the key infrastructures and to give recommendations for their further development .

\section{The basis: existing monitoring} sites and research networks

A number of transnational European networks related to forest research and monitoring have been identified at the conference as potential target users and are presented in more detail (Tab. 1, Box 1).

ICP Forests has since more than 25 years
European forest monitoring and research $\square$ (1) Johann Heinrich von Thünen-Institute, Instit. for World Forestry, Leuschnerstrasse 91, D-21029 Hamburg (Germany); (2) Norwegian Instit. for Air Research, P.O. Box 100, N-2027 Kjeller (Norway); (3) Alterra, Wageningen University and Research Centre, P.O. Box 47, NL-6700 AA Wageningen (The Netherlands); (4) Norwegian Forest and Landscape Inst., P.O. Box 115, N-1431 Ås (Norway); (5) Institute of Systems Biology and Ecology Academy of Science of the Czech Republic, Na Sadkach 7, CS-370 05 Ceske Budejovice (Czech Republic); (6) NERC Centre for Ecology \& Hydrology (Edinburgh), Bush Estate, EH26 OQB Penicuik (UK); (7) Swedish University of Agricultural Sciences, P.O. Box 7050, S-75007 Uppsala (Sweden); (8) CNR - Instit. for Agricultural and Forestry Systems in the Mediterranean, v. Cavour 4-6, I-87036 Rende (CS, Italy); (9) Ecophysiology of Plants, Technische Universität München, von-Carlowitz-Platz 2, D85354 Freising (Germany); (10) Riso National Laboratory for Sustainable Energy, Technical University of Denmark, Frederiksborgvej 399, DK-4000 Roskilde (Denmark); (11) Federal Environment Agency Austria, Spittelauer Lände 5, 1090 A-Vienna (Austria); (12) DISAFRI, Università della Tuscia, v. San Camillo de Lellis, I-01100 Viterbo (Italy);

(13) Croatioan Forest Research Instit., Cvjetno Naselje 41, 10450 Jastrebarsko (Croatia); (14) EMEP MSC-W, Norwegian Meteorological Institute, Postboks 43, Blindern, N-0313 Oslo (Norway); (15) Finnish Meteorological Instit., P.O. Box 503, Fl-00101 Helsinki (Finland); (16) University of Helsinki, P.O. Box 48, 00014 SF-Helsinki (Finland); (17) Federal Office and Research Centre for Forests, Rennweg 1, A-6020 Innsbruck (Austria); (18) CNR - Instit. for Plant Protection, v. Madonna del Piano 10, I-50019 Sesto Fiorentino (Firenze, Italy)

(a) Richard Fischer (richard.fischer@vti.bund.de)

Received: Dec 21, 2010 - Accepted: Mar 24, 2011

Citation: Fischer R, Aas W, De Vries W, Clarke N, Cudlin P, Leaver D, Lundin L, Matteucci G, Matyssek R, Mikkelsen TN, Mirtl M, Öztürk Y, Papale D, Potocic N, Simpson D, Tuovinen J-P, Vesala T, Wieser G, Paoletti E 2011. Towards a transnational system of supersites for forest monitoring and research in Europe - an overview on present state and future recommendations. iForest 4 : 167-171 [online 2011-08-11] URL: http://www.sisef.it/iforest/show.php? id $=584$

monitored forest condition aiming, at the same time, to establish relationships to natural and anthropogenic stress factors. Moni- 
Tab. 1 - Overview of transnational forest monitoring and research networks in Europe.

\begin{tabular}{|c|c|c|c|}
\hline Programme & $\begin{array}{l}\text { Full name } \\
\text { (Web page) }\end{array}$ & $\begin{array}{l}\text { Legal basis/ } \\
\text { Financing }\end{array}$ & Sites \\
\hline ICP Forests & $\begin{array}{l}\text { International Cooperative Programme on Assessment } \\
\text { and Monitoring of Air Pollution Effects on Forests } \\
\text { (http://www.icp-forests.org) }\end{array}$ & $\begin{array}{l}\text { UNECE, } \\
\text { CLRTAP }\end{array}$ & $\begin{array}{l}6000 \text { Low intensity sites } \\
500 \text { Intensive forest monitoring sites, from these ap- } \\
\text { prox } 100 \text { intensified FutMon sites }\end{array}$ \\
\hline $\begin{array}{l}\text { ICP Integrated } \\
\text { Monitoring }\end{array}$ & $\begin{array}{l}\text { International Cooperative Programme on Integrated } \\
\text { Monitoring of Air Pollution Effects on Ecosystems } \\
\text { (http://www.environment.fi/default.asp? } \\
\text { contentid=17110\&lan=en) }\end{array}$ & $\begin{array}{l}\text { UNECE, } \\
\text { CLRTAP }\end{array}$ & 44 catchment sites, 39 incl. forests \\
\hline EMEP & $\begin{array}{l}\text { European Monitoring and Evaluation Programme } \\
\text { (http://www.emep.int) }\end{array}$ & $\begin{array}{l}\text { UNECE, } \\
\text { CLRTAP }\end{array}$ & $\begin{array}{l}\text { Number of sites is depending on compound. In gene- } \\
\text { ral, about } 100 \text { Level I sites (e.g., ozone, main com- } \\
\text { ponents) and } 25 \text { Level II sites -joint EMEP/GAW } \\
\text { supersites with more advanced measurements }(e . g . \text {, } \\
\text { POPs, aerosol properties, VOC). } \\
\text { About 10-15 EMEP sites are located in forest. More } \\
\text { sites with partly forested areas. }\end{array}$ \\
\hline NitroEurope & $\begin{array}{l}\text { European research into the nitrogen cycle } \\
\text { (http://www.nitroeurope.eu) }\end{array}$ & $6 \mathrm{FP}$ & $\begin{array}{l}\text { Component } 1 \text { (Observational network) } \\
4 \text { forest sites Level III (Supersites, } 500 \text { parameters) } \\
2 \text { forest sites Level II ( } 100 \text { parameters) } \\
24 \text { forest sites Level I (low cost active sampler } 100 \\
\text { parameters) } \\
\text { Component } 2 \text { (Manipulation network) } \\
7 \text { forest sites } \\
\text { (additional non-forest sites available) }\end{array}$ \\
\hline $\begin{array}{l}\text { CarboEurope / } \\
\text { Fluxdata }\end{array}$ & $\begin{array}{l}\text { CarboEurope-IP Assessment of the European } \\
\text { Terrestrial Carbon Balance } \\
\text { (http://www.carboeurope.org) }\end{array}$ & $6 \mathrm{FP}$ & $\begin{array}{l}54 \text { Atmospheric observation sites } \\
106 \text { Ecosystem observation sites } \\
\text { ( } 58 \text { forest sites) }\end{array}$ \\
\hline ICOS & $\begin{array}{l}\text { Integrated Carbon Observation System } \\
\text { (http://www.icos-infrastructure.eu) }\end{array}$ & 7 FP/ESFRI & $\begin{array}{l}\text { Current plans: installation of approx. } \\
50 \text { atmospheric sites } \\
50 \text { ecosystem sites } \\
\text { final information on ecosystems represented not yet } \\
\text { available } \\
10 \text { ocean sites }\end{array}$ \\
\hline LTER Europe & $\begin{array}{l}\text { European Long-Term Ecosystem Research Network } \\
\text { (http://www.lter-europe.net) }\end{array}$ & $\begin{array}{c}6 \text { FP } \\
\text { (ALTERNET) } \\
\text { ILTER ESFRI } \\
\text { (LIFEWATCH) }\end{array}$ & $\begin{array}{l}400 \text { LTER sites ( } 30 \% \text { forested) } \\
25 \text { LTSER platforms }\end{array}$ \\
\hline
\end{tabular}

toring is carried out on plots in two intensity levels. The surveys follow harmonized procedures (ICP Forests 2010) and have been co-financed over many years by the European Commission. Under the LIFE FutMon project the number of intensive monitoring plots has been reduced in order to intensify assessments on the remaining sites (Lorenz 2010, Fischer et al. 2010).

ICP Integrated Monitoring carries out monitoring on forested catchment sites. Among those, a larger proportion is in unmanaged forests. Monitoring is divided into a number of compartmental subprogrammes which are linked by the use of the same parameters (cross-media flux approach) and/or same/nearby stations (cause- effect approach). Methods are partly harmonized with the ICP Forests (De Vries et al. 2002, Kleemola \& Forsius 2010).

EMEP is assessing the transboundary transport of acidifying and eutrophying pollutants, heavy metals and particulate matter. It also addresses the formation of ground level ozone and of persistent organic pollutants (POPs). The EMEP programme relies on three main elements: (i) collection of emission data; (ii) measurements of air and precipitation quality; and (iii) modelling of atmospheric transport and deposition of air pollutants (EMEP 2010).

NitroEurope is a project for integrated European research into the nitrogen cycle in different ecosystems. The focus is on the ef- fect of reactive nitrogen supply on net greenhouse gas budgets for Europe. It is part of the EU's Sixth Framework Programme for Research and Technological Development and will run until early 2011. It follows a combined approach integrating monitoring and experiments with sites with different intensities of measurements (NEU 2010).

CarboEurope was a project that aimed at understanding and quantifying the present terrestrial carbon balance of Europe through assessment of the European carbon balance, understanding of the mechanisms of carbon cycling in relation to climate change and human management, and developing an observation system for atmospheric $\mathrm{CO}_{2}$ concentrations and ecosystem carbon fluxes (Car- 
boEurope 2010). This integrated project established the largest network of eddy covariance measurement sites in Europe, originating from some previous EU projects (CarboEuroFlux, Greengrass, Carbomont). Even though CarboEurope was finished in 2008, the project initiated a community that continues to collaborate and share data, even without direct funding, and with the support from other research projects on carbon cycling such as CarboExtreme, IMECC and GHG-Europe. Today, 58 of these sites are located in a forested environment. The system is currently under reorganization including the construction of a unique database system (Fluxdata-Europe) providing access to the data..

ICOS is a European Research Infrastructure for quantifying and understanding the greenhouse balance of the European continent and of adjacent regions. After a preparatory phase, funded by the EU and ending in 2012 , ICOS is intended to run for the next 20 years with a minimum of 30 sites. It builds among others on selected NitroEurope and CarboEurope sites (ICOS 2010) but it will be based on highly standardized methodologies and equipments which will be the main difference from the rest of the canopy flux sites that will continue to operate and share data under the FluxdataEurope system. As an ESFRI (European Strategy Forum on Research Infrastructures) programme, ICOS is supported but not funded by the EU and hence the funding needs to be connected to national agencies.

LTER-Europe is a network of research infrastructures and institutions involved in ecological research. It is built on national networks and is aiming also at a virtual European ecological research institute. It links sites, researchers and scientific site managers and provides links to data owners It is a platform for the establishment of ecological research projects (LTER 2010).

\section{Analysing existing monitoring and research infrastructure}

Based on presentations from the above mentioned programmes and on discussions at the COST FP0903 conference the present situation of monitoring and research networks can be characterized as follows:

- A number of valuable and successful monitoring and research networks already exist, providing important information and partly long-term time series on various aspects of forest ecology, surface fluxes, atmospheric physics and chemistry and air quality.

- Existing networks are mostly focused on specific topics (e.g., carbon, nitrogen, air pollution, ...) and are sparsely interlinked. However, a number of sites are already contributing to more than one transnational network.

Box 1 - List of abbreviations.

The following abbreviations are used along the text:

- FP6 - Sixth EU Framework Programme for Research and Technical Development

- FP7 - Seventh EU Framework Programme for Research and Technical Development

- CLRTAP - Convention on Long-range Transboundary Air Pollution

- COST - European Cooperation in Science and Technology

- EMEP - Co-operative programme for monitoring and evaluation of the long range transmission of air pollutants in Europe

- ESFRI - European Strategy Forum on Research Infrastructures

- EU - European Union

- GHG - Europe - Greenhouse gas management in European land use system

- ICOS - Integrated Carbon Observation System

- ICP - International Cooperative Programme

- ILTER - International Long-Term Ecosystem Research Network

- IMECC - Infrastructure for Measurements of the European Carbon Cycle

- LTER - Long Term Ecological Research Network

- UNECE - United Nations Economic Commission for Europe

- Scientific use of data beyond the specific networks gathering the information is usually limited, because on one hand the knowledge on existing monitoring and research networks is limited and on the other hand data availability and exchange is difficult (Clarke et al. 2011).

- A separation into classical approaches of monitoring and research is perceived as artificial. Independent, separate goals and aims continue to exist, but continuous and long-term data from a sufficiently large number of monitoring plots are becoming increasingly important for research, including model testing and validation. Also, monitoring infrastructures in many cases constitute a basis for experimental research and empirical cause-effect studies rely on such data sets. Monitoring results provide input for new research. On the other hand, experimental research is an important and necessary driver for the development of monitoring methods

- The operation of the sites usually relies on national budgets. In addition, most networks are co-financed through temporarily limited external funds. Existing funding schemes are mostly too narrow, as they support either "scientific research" or "monitoring" projects and programmes. In reality, however, experiments are often linked to monitoring sites. On the other hand, monitoring in many cases requires technical "high-tech" installations that funding schemes perceived as experimental instrumentation even if no ecosystem manipulation occurs.

- All transnational networks presented are coordinated by a central institute or agency and operate sites through national institutions that serve as partners or national focal points. Within single countries, national focal points for different international networks often operate under different institutions which can hamper the necessary cooperation (Tab. 2).
- Most networks are built on a hierarchical approach, with sites under different monitoring and research intensities and often include a modelling and up-scaling components.

- The number of countries participating in the different networks in Europe varies among the different programmes (Tab. 2).

\section{Towards integration: science and policy recommendations}

An important improvement of the existing forest monitoring and research infrastructures can be obtained by combining longterm experiments with ecosystem-level monitoring and with ecosystem modelling. There is a strong need for harmonized longterm monitoring data to detect climate change impacts on forest ecosystems such as changes in tree growth and carbon allocation, changes in forest health or alterations in soil chemistry and water budgets. Monitoring data in combination with realistic experiments will allow translating the mechanistic forest ecosystem understanding into predictive models and into a more accurate risk assessment. Interactions between forest ecosystems and the atmosphere, including $\mathrm{CO}_{2}$ exchange, ozone uptake (exposure), nitrogen deposition and biogenic aerosols are among the most relevant topics in this respect. It is specifically recommended to:

- continue the analysis and compilation of information from existing long-term monitoring data sets with regard to different research objectives, including evaluations of impacts of air pollution and climate change on forest ecosystem services. Such forest ecosystem services include: (i) species, forest ecosystem and genetic diversity; (ii) water quality regulation through the buffer and filter function of the soils; and (iii) climate regulation through carbon sequestration.

- further develop, test and if suitable apply a joint classification of existing sites in order 
Tab. 2 - Institutional responsibilities for different networks within participating countries. For all programmes the contact addresses of all national focal points were identified via the networks' homepages. Same letters within a country indicate the same institution being responsible for the respective programmes. Different letters within a country indicate different responsibilities for different programmes. (mult.): more than one institution per country participating in the programme.

\begin{tabular}{|c|c|c|c|c|c|c|c|}
\hline Country & $\begin{array}{c}\text { ICP } \\
\text { Forests }\end{array}$ & ICP IM & LTER & ICOS & $\begin{array}{c}\text { Carbo } \\
\text { Europe }\end{array}$ & $\begin{array}{c}\text { Nitro } \\
\text { Europe }\end{array}$ & EMEP \\
\hline Albania & $\mathrm{a}$ & - & - & - & - & - & - \\
\hline Andorra & $\mathrm{a}$ & - & - & - & - & - & - \\
\hline Austria & $\mathrm{a}$ & $\mathrm{b}$ & $\mathrm{b}$ & - & $\mathrm{a}, \mathrm{d}$ & $a, f$ & $\mathrm{~b}$ \\
\hline Belarus & $\mathrm{a}$ & $\mathrm{b}$ & $\mathrm{c}$ & - & - & - & $\mathrm{e}$ \\
\hline Belgium & $\mathrm{a}$ & - & $\mathrm{a}$ & $\mathrm{d}$ & d (mult.) & $\mathrm{f}$ & $\mathrm{e}$ \\
\hline Bosn. Herzegov. & - & - & - & - & - & - & - \\
\hline Bulgaria & $\mathrm{a}$ & - & $\mathrm{c}$ & - & - & - & $\mathrm{e}$ \\
\hline Croatia & $\mathrm{a}$ & - & $\mathrm{c}$ & - & - & $\mathrm{f}$ & $\mathrm{f}$ \\
\hline Cyprus & $\mathrm{a}$ & - & - & - & - & - & $\mathrm{e}$ \\
\hline Czech Rep. & $\mathrm{a}$ & b (mult.) & $\mathrm{c}$ & $\mathrm{d}$ & $\mathrm{d}$ & - & $\mathrm{b}$ \\
\hline Denmark & $\mathrm{a}$ & - & $\mathrm{c}$ & $\mathrm{d}$ & a (mult.) & a (mult.) & $\mathrm{c}$ \\
\hline Estonia & $\mathrm{a}$ & $\mathrm{b}$ & $\mathrm{c}$ & - & - & $\mathrm{c}$ & $\mathrm{e}$ \\
\hline Finland & $\mathrm{a}$ & $\mathrm{b}$ & $\mathrm{b}$ & d (mult.) & d (mult.), e & b,d,e (mult.) & $\mathrm{e}$ \\
\hline France & $\mathrm{a}$ & - & $\mathrm{c}$ & $\mathrm{d}$ & d (mult.), c & $\mathrm{c}, \mathrm{d}$ (mult.) & $\mathrm{e}$ \\
\hline Germany & $\mathrm{a}$ & $\mathrm{b}$ & $\mathrm{c}$ & $\mathrm{d}$ & $\mathrm{d}$ & d (mult.) & $\mathrm{b}$ \\
\hline Greece & $\mathrm{a}$ & - & - & - & - & - & $\mathrm{e}$ \\
\hline Hungary & $\mathrm{a}$ & - & $\mathrm{c}$ & - & $\mathrm{f}$ & f (mult.) & $\mathrm{e}$ \\
\hline Iceland & - & b & - & - & - & - & $\mathrm{e}$ \\
\hline Ireland & $\mathrm{a}$ & - & $\mathrm{c}$ & $\mathrm{d}$ & f (mult.) & f (mult.) & $\mathrm{d}$ \\
\hline Italy & $\mathrm{a}$ & $\mathrm{a}$ & $\mathrm{c}$ & $\mathrm{d}$ & c,d (mult.) & c (mult.), d & $\mathrm{c}$ \\
\hline Latvia & $\mathrm{a}$ & $\mathrm{b}$ & $\mathrm{c}$ & - & - & - & $\mathrm{b}$ \\
\hline Liechtenstein & $\mathrm{a}$ & - & - & - & - & - & - \\
\hline Lithuania & $\mathrm{a}$ & $\mathrm{b}$ & $\mathrm{c}$ & - & - & - & $\mathrm{e}$ \\
\hline Luxembourg & $\mathrm{a}$ & - & - & - & - & - & - \\
\hline FYR of Macedonia & $\mathrm{a}$ & - & - & - & - & - & $\mathrm{e}$ \\
\hline Malta & - & - & - & - & - & - & $\mathrm{e}$ \\
\hline Rep.of Moldova & $\mathrm{a}$ & - & - & - & - & - & $\mathrm{e}$ \\
\hline Montenegro & $\mathrm{a}$ & - & - & - & - & - & $\mathrm{e}$ \\
\hline The Netherlands & $\mathrm{a}$ & b & $\mathrm{c}$ & $\mathrm{d}$ & c,d (mult.) & c, d (mult.) & $\mathrm{b}$ \\
\hline Norway & $\mathrm{a}$ & b (mult.) & $\mathrm{c}$ & $\mathrm{d}$ & - & $\mathrm{f}$ & $\mathrm{f}$ \\
\hline Poland & $\mathrm{a}$ & - & $\mathrm{c}$ & $\mathrm{d}$ & d (mult.) & d (mult.) & $\mathrm{e}$ \\
\hline Portugal & $\mathrm{a}$ & - & $\mathrm{c}$ & $\mathrm{d}$ & d (mult.) & - & $\mathrm{e}$ \\
\hline Romania & $\mathrm{a}$ & - & $\mathrm{c}$ & - & - & - & $\mathrm{e}$ \\
\hline Russian Fed. & $\mathrm{a}$ & - & $\mathrm{c}$ & - & - & $\mathrm{f}$ & $\mathrm{e}$ \\
\hline Serbia & $\mathrm{a}$ & - & $\mathrm{c}$ & - & - & - & $\mathrm{e}$ \\
\hline Slovak Rep. & $\mathrm{a}$ & - & $\mathrm{c}$ & - & - & $\mathrm{f}$ & $\mathrm{f}$ \\
\hline Slovenia & $\mathrm{a}$ & - & $\mathrm{c}$ & - & - & - & $\mathrm{e}$ \\
\hline Spain & $\mathrm{a}$ & $\mathrm{b}$ & $\mathrm{c}$ & $\mathrm{d}$ & d (mult.) & d (mult.) & $\mathrm{e}$ \\
\hline Sweden & a (mult.) & b (mult.) & $\mathrm{b}$ & $\mathrm{d}$ & b (mult.) & d, e (mult.) & $\mathrm{e}$ \\
\hline Switzerland & $\mathrm{a}$ & $\mathrm{a}$ & $\mathrm{a}$ & $\mathrm{d}$ & d (mult.) & - & $\mathrm{e}$ \\
\hline Turkey & $\mathrm{a}$ & - & $\mathrm{c}$ & - & - & - & $\mathrm{e}$ \\
\hline Ukraine & $\mathrm{a}$ & - & - & - & - & $\mathrm{f}$ & $\mathrm{e}$ \\
\hline United Kingdom & $\mathrm{a}$ & $\mathrm{b}$ & $\mathrm{b}$ & $\mathrm{d}$ & b,d (mult.) & b (mult.), d & $\mathrm{e}$ \\
\hline
\end{tabular}

to enable communication between managers of different networks. A possible classification system has already been elaborated by LTER and will be tested in the EnvEurope project (ENVEurope 2010).

- establish an integrated system of monitoring and research sites covering the main European forest types, being open for use by different research groups, and being secured by stable long term funding.

- base such an integrated system on a hierarchical monitoring and research infra- structure built on: (i) a limited number of highly instrumented "supersites", where all ecosystem compartments and fluxes are covered, including experimental approaches and aiming at gaining insight into mechanistic processes (e.g., energy, water, carbon, nitrogen, ozone, volatile organic compounds, particles, biodiversity); and (ii) a larger number of less equipped intensive monitoring plots covering larger ecological gradients and providing data with higher spatial representation. These

plots should, however, be linked to the "supersites", representing similar ecozones and forest types for example; and (iii) a gridded network of forest inventories or basic-monitoring plots.

- build such an integrated system on existing networks and data which need to be linked in order to enable harmonisation of assessments and efficient data flows (Clarke et al. 2011). New infrastructure is needed primarily for coordination and harmonisation of existing systems and to a lesser extent for the creation of new sites.

- encourage closer links between the communities of experimentalists, monitoring experts and modellers.

- support and continue collaboration and contacts between existing networks and their coordinating centres on the transnational level but also support collaboration on the national level, as the desired creation and joint use of sites can only be achieved through collaboration of the national site managing institutions.

The creation of a transnational system of supersites for forest monitoring and research can only be achieved if scientists from different disciplines and managers from different existing networks are involved. The COST Action FP0903 will run until 2013 offering the possibility to continue the dialogue and to support the development of such a system.

\section{Acknowledgements}

The article is a joint paper of the COST Action FP0903 "Climate Change and Forest Mitigation and Adaptation in a Polluted Environment". We wish to thank all scientists and experts contributing to the discussions at the action's conference on 5-7 October 2010 in Rome, and the COST office for supporting the conference.

\section{References}

Bytnerowicz A, Omasa K, Paoletti E (2007). Integrated effects of air pollution and climate change on forest: a northern hemisphere perspective. Environmental Pollution 147: 438-445. - doi: 10.1016/j.envpol.2006.08.028

CarboEurope (2010). Integrated Project CarboEurope-IP: assessment of the european terrestrial carbon balance. [online] URL: http://www.carboeurope.org

Clarke N, Fischer R, De Vries W, Lundin L, Paoletti E, Merilä P, Matteucci G, Mirtl M, Simpson D, Vesala T (2011). Availability, accessibility, quality and comparability of monitoring data for European forests for use in air pollution and climate change science. iForest (in press) - doi: 10.3832/ifor0582-004

COST (2010). Action 0903 [online] URL: http://cost-fp0903.ipp.cnr.it/

De Vries W, Forsius M, Lorenz M, Lundin L, Haussman T, Augustin S, Ferretti M, Kleemola S, Vel E (2002). Cause-effect relationships of 
forest ecosystems. Joint report by ICP Forests and ICP Integrated Monitoring. Report for United Nations Economic Commission for Europe. Federal Research Centre for Forestry and Forest Products (BFH) - Finnish Environment Institute (SYKE), pp. 46. [online] URL: http://www.icp-forests.org/pdf/icpf-icpim.pdf

EEA (2004). Air pollution and climate change policies in Europe: exploring linkages and the added value of an integrated approach. Technical Report 5/2004, European Environment Agency, Copenhagen, Denmark, pp. 89. [online] URL: http://www.eea.europa.eu/publications/technical report_2004_5

EMEP (2010). Welcome to EMEP (European Monitoring and Evaluation Programme). [online] URL: http://www.emep.int

ENVEurope (2010). ENVEurope Project - Environmental quality and pressures assessment across Europe. [online] URL: http://www.enveurope.eu

Fischer R, Lorenz M, Köhl M, Mues V, Granke O,
Iost S, van Dobben H, Reinds GJ, de Vries W (2010). The condition of forests in Europe. 2010 Executive Report, ICP Forests, Hamburg, Germany, and European Commission, Brussels, Belgium, pp. 20. [online] URL: http://www.icpforests.org/RepEx.htm

Fischer R (2008). Forest ecosystems in a changing environment: identifying future monitoring and research needs. COST Strategic Workshop, Istanbul (Turkey) 11-13 March 2008. [online] URL: http:/www.icp-forests.org/pdf/COST.pdf ICOS (2010). ICOS Integrated Carbon Observation System. [online] URL: http://www.icos-infrastructure.eu

ICP Forests (2010). Manual on methods and criteria for harmonized sampling, assessment, monitoring and analysis of the effects of air pollution on forests. UNECE, ICP Forests, Hamburg, Germany. ISBN: 978-3-926301-03-1. [online] URL: http://www.icp-forests.org/Manual.htm

Kleemola S, Forsius M (2010). 19 ${ }^{\text {th }}$ Annual Report 2010. Convention on long-range transboundary air pollution. International Cooperative Programme on Integrated Monitoring of Air Pollution Effects on Ecosystems. The Finnish Environment 15: 49. [online] URL: http://www.environment.fi $/$ default.asp? contentid $=365563 \&$ lan $=$ en\&clan $=$ en

Lorenz M (2010). Objectives, strategy and implementation of ICP Forests. Manual Part I. In: "Manual on methods and criteria for harmonized sampling, assessment, monitoring and analysis of the effects of air pollution on forests". UN ECE, ICP Forests, Hamburg, Germany, pp. 21 [online] URL: http://www.icp-forests.org/Manual.htm

LTER (2010). European Long-Term Ecosystem Research Network. [online] URL: http://www.1ter-europe.net/

NEU (2010). NitroEurope IP. The nitrogen cycle and its influence on the European greenhouse gas balance. [online] URL: http://www.nitroeurope.eu/ 